\title{
実装技術の重要性と環境調和型実装技術
}

\section{Importance of Mounting Technology and Environment-friendly Packaging Technology}

\author{
環境調和型実装技術委員会 環境亡実装研究会
}

\section{1．エレクトロニクス産業と実装技術}

21 世紀になり早 15 年になります。皆様と日本，世界に とり 2015 年は良い年でありますように。さて，日本の現状 はどうでしょう？世界の情勢は？ IPCC は第 5 次報告書で 地球温暖化は確実に進行しており，人間の活動に起因する 確率は $95 \%$ 以上であると報告しています。西暦 1 年頃に推 定 1 億人だった世界人口は 1,000 年かけて 2 倍の推定 2 億 人になり, 産業革命前に約 7 億人になりました。この後, 人口は急速に増加し現在, 約 72 億人に達しました。この急 激な増加の傾向はさまざまな現象に現れ，簡単には図 1 の ような傾向を示します ${ }^{1)}$ 。この間，急激な技術の進歩は, 人間の寿命を長くし, 物質的な豊かさを与え, 人口の増加 と二酸化炭素の増加による地球温暖化，さまざまな環境問 題と社会問題をもたらしています。皆さんは物質的に豊か になったことで, 生活や精神面, 家族・親戚・友人の関係 で幸福を感じますか？絆は強くなりましたか？ 社会の豊 かさを表す指標はいくつかありますが GDP（国内総生産） の他に地球幸福度指数があります。地球幸福度指数は GDP や経済成長と正確には一致しない傾向があります。これは 精神的な豊かさが物質だけでないことを示します。今，科 学技術が行うべきことは何か? 行くべき方向はどこか? 実装技術と電気電子産業そして環境調和から考元ましょう。

エレクトロニクス実装技術は，はんだ接続や部品搭載か ら半導体, 電子部品, 配線板, 部品内臟基板, システム設 計，シミュレーション，評価・検査技術，関連材料，環境

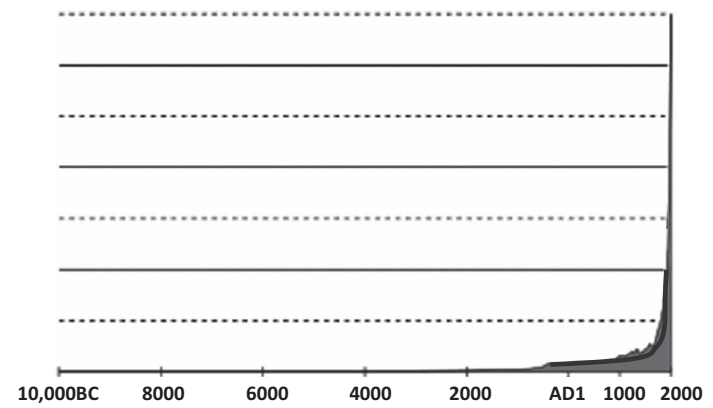

図 1. 人類の歴史 : 急激な増加の傾向 (人口・1 次エネル ギ使用量・ $\mathrm{CO}_{2}$ 排出量など）
技術，実装設備など多岐に渡ります。エレクトロニクス産 業の歴史を見ると，エジソンが 1879 年に白熱電球を発明し てから, 日本は 1900 年ころ家庭に電球が入り, 扇風機など も出てきました。家庭電化製品で考えると 1950 年代にさま ざまな家電製品が生活の中に入って来ました。蛍光灯，ラ ジオ, ブラウン管 $\mathrm{TV}$, 冷蔵庫, 洗濯機, 自動式電気釡, 電気こたつなどです。これにより主婦の生活は変わってき ます。70 年代になると現在とほほ同じ家電製品が揃い，生 活様式もほほ同じようになります。ステレオに代表される 音響機器，モバイル機器も出ます。 80 年代になると家電製 品は，基本機能はほぼ同じですが，より洗練されて来ます。 ウォッシュレット, CD プレーヤー, ビデオ，自動パン焼 き機など嗜好品が多くなります。2000 年代になると TV は 薄型になり液晶 TV が主流になります。エアコンの家庭へ の設置は当たり前, 冷蔵庫は大型化し広い泠凍室が付きま す。LED 照明，パソコンを使いインターネットを利用， DVD や Blu-ray Disc，半導体メモリの記録メディア，携帯 電話など携帯機器の普及，家は PV パネルの設置による太 陽光の利用など多岐に渡ります。それぞれの製品はより洗 練され新しい機器が出ます。現在は，スマートホン， ロ ボット掃除機，布団クリーナー (ダニ除菌)，ウエアラブル デバイス，3D プリンタ，クラウド健康管理機器，海外では 空気清浄機（対 PM2.5）などです。表 1 に簡単にまとめま す。いろいろありますが，これらのエレクトロニクス製品 の設計，製造に実装技術は必要不可欠です。そして製品の 高性能化, 信頼性, 品質, 高機能と小型化などを支えてい ます。実装技術はこれらの製品，生活様式と共に成長して きました。けれども，製品をよく見ると人間が生活の中で 使用するものですから目的と基本は手作業で行っていた時 と変わって扔らず，電気がなくなった場合には，人が行う ことができる内容のものを家電製品で代用しているだけで す。製品もある程度，予想できます。

そのような中で 1990 年代ころまでは日本のエレクトロニ クス産業は世界でトップでした。世界の多くの家庭は家電 製品を持つことが夢で，日本製 (Made in Japan) はステータ スでした。いつから世界は変って行ったのでしょうか？ それは 1980 年代ころから段階的に始まりました。日本の電 
表 1. 主な家電製品の登場

\begin{tabular}{|c|c|c|c|c|c|c|c|}
\hline 1950 以前 & 1950 年代 & 1960 年代 & 1970 年代 & 1980 年代 & 1990 年代 & 2000 年代 & 2010 年代 \\
\hline $\begin{array}{l}\text { 白熱電球 } \\
\text { アイロン } \\
\text { 扇風機 } \\
\text { ラジオ } \\
\text { 洗濯機 } \\
\text { 冷蔵庫 } \\
\text { 蓄音機 } \\
\text { 掃除機 } \\
\text { ミシン } \\
\text { Etc. }\end{array}$ & $\begin{array}{l}\text { トースター } \\
\text { ドライヤー } \\
\text { テープ } \\
\quad \text { レコーダー } \\
\text { 白黒 TV } \\
\text { トランジスタ } \\
\quad \text { ラジオ } \\
\text { 炊飯器 } \\
\text { こたつ } \\
\text { Etc. }\end{array}$ & $\begin{array}{l}\text { インターホン } \\
\text { トランジスタ } \\
\text { TV } \\
\text { カラーTV } \\
\text { 空気清浄機 } \\
\text { ラジカセ } \\
\text { 電卓 } \\
\text { 電子レンジ } \\
\text { プッシュホン } \\
\text { Etc. }\end{array}$ & $\begin{array}{l}\text { 省エネ家電 } \\
\text { 蛍光灯 } \\
\text { TV, 冷蔵庫 } \\
\text { VTR } \\
\text { ビデオカメラ } \\
\text { 全自動洗濯機 } \\
\text { ファンヒーター } \\
\text { パソコン } \\
\text { Walkman } \\
\text { Etc. }\end{array}$ & \begin{tabular}{l} 
大型家電 \\
\multicolumn{1}{c}{$\mathrm{TV}$, 冷蔵庫 } \\
オーディオ \\
カード電卓 \\
温水洗浄便座 \\
$\mathrm{LD}, \mathrm{CD}$, \\
液晶 $\mathrm{TV}$ \\
ゲーム機 \\
$8 \mathrm{~mm}$ ビデオ \\
Etc.
\end{tabular} & $\begin{array}{l}\text { 環境家電 } \\
\text { 生ゴミ処理機 } \\
\text { 掃除機 } \\
\text { エアコン } \\
\text { 冷蔵庫 } \\
\text { RoHS 対応 } \\
\text { MD, DVD, } \\
\text { コードレス電話 } \\
\text { AIBO } \\
\text { Etc. }\end{array}$ & $\begin{array}{l}\text { デジタル家電 } \\
\text { iPod, DVD } \\
\text { デジカメ } \\
\text { 薄型 TV } \\
\text { オール電化 } \\
\text { 電磁調理器 } \\
\text { 床暖房 } \\
\text { エコキュート } \\
\text { BD, Blu-ray, SS, } \\
\text { Etc. }\end{array}$ & $\begin{array}{l}\text { スマート家電 } \\
\text { ウェアラブル } \\
\text { クラウド } \\
\text { スマートフォン } \\
\text { 3D, 3D プリンタ } \\
\text { ロボット掃除機 } \\
\text { 健康管理機 } \\
\text { 空気清浄機 } \\
\text { ダニ除菌機器 } \\
\text { ハイレゾ..??? }\end{array}$ \\
\hline
\end{tabular}

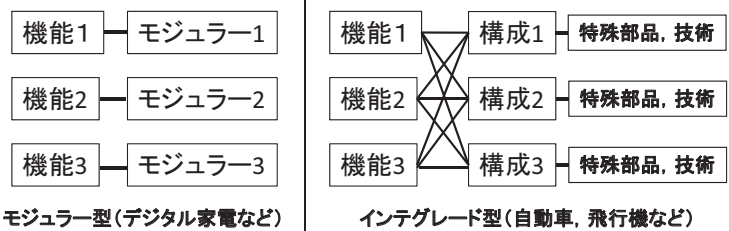

図 2. 製品アーキテクチャ (概念 $)^{2)}$

子産業は, これまで何度も危機に陥りました。1990 年代前 半のバブル崩壊， 2000 年代初頭の IT バブル崩壊などです。 2006 年から 2007 年にかけて大手家電メーカを中心に事業 の再編が行われましたが，2007年を境に日本の電機の貿易 黒字は急激に縮小に向かい産業の空洞化が進みました。決 定的だったのは 2008 年 9 月のリーマンショックです。現 在, デジタル家電の次の展開が見つかりません。このよう な状況に次の理由が日本のエレクトロニクス産業の衰退に 拍車をかけたのです 2),3)。ボクシングを例にするとリーマン ショックでいままでのボディーブローが一気に効いてきた 感じです。

（1）デジタル化とモジュール化の進展で差別化が難しく なり，日本の強みが活かせない。

デジタル化はオーデイオや映像から始まり 1982 年頃から $\mathrm{CD}$ が出ました。そして, 液晶 TVになり映像のデジタル化 が一般的になります。2011 年に日本のテレビジョン放送 は，地上アナログの放送終了ならびに地上デジタル放送へ の切り替えを行いました。デジタル化の進展で, 組み込み ソフトで制御された工業製品が急増しました。そして極端 に言うとパーッ間のインターフェイスを標準化すればパー ツを組み合わせることでどこの国でも部品があれば製品を 完成できるようになったのです。ここには日本がアナログ 技術や小型のメカニカル部品で得意としていた素晴らしい 技術は必要ありません。これにより家電製品のアーキテク チヤは，インテグレード型からモジュラー型に変わりまし た。図 2 に簡単な概念を示します。私達は，本当はインテ グレード型が優れており, 日本はこれから特にこれで勝負 すべきと考えます。

（2）日本企業が製造「ものつくり」を大切にしなくなっ た。EMS 産業が海外で台頭した。

日本のメーカは「ものつくり」を大切にしていました。 研究開発だけでなく, 個々の技術, 人の技能を大切にし,
製造の know-how から歩留，品質に至るまで真摰に取り組 んでいました。「ものつくり」と共に「技術」と「作る人」 を大切にしていました。けれども一見心地よさそうな「ア ウトソーシング」の言葉で，製造を海外の EMS（electronics manufacturing service：製造請負）などに委ねました。メー カの know-how や根幹をなす技術，製造管理，品質管理な ど大切なものと共に人材も海外に流出して行きました。驚 いたことに品質管理，クレーム対応まで EMS に任せる議 論もありました。その時の何人かの経営者は, 先輩達の代 から日本が今まで培ってきたものの重みと大切さを理解で きなかったのかもしれません。

（3）間違ったグローバル化を進め，その結果，コスト競 争になった。

1980 年代にもグローバリゼーションはありました。この 時はマーケットオリエンテッドでした。市場のあるところ で生産し，日本，US，ヨーロッパなどが主体でした。これ により材料調達の潤滑化，輸送コストの削減，現地で適切 な雇用が生まれました。製造や輸送に当たり公害防止対策 もきちんと取り，環境に配慮していました。けれども 1990 年代後半になるとコストオリエンテッドに転換してきまし た。単に賃金の安いところでものを作るという実際にはグ ローバリゼーションに名を借りた一国集中の究極のローカ ライゼーションが起こりました。この時にも日本の大切な 製造と工場管理などの know-how は簡単に流出して行きま した。今はさらに低コストを求め, 主にアジア地域に広 がっています。

（4）日本企業の足並みか活しれ，技術の衰退の時期を早めた。 例えば液晶 TV の場合, 日本が開発し, 主要部品の液晶 パネルも優位を保っていました。けれども国内メーカ間の 競争の激化と意地で他国と提携する企業が出ました。ここ から今まで培ってきた日本の技術と人材がエレクトロニク ス分野で追い上げている国に流出して行ったことは否めま せん。結果は見て分かる通りです。別の例では，日本の記 録メディア技術です。記録は人類にとって非常に重要で す。この分野は, 日本が世界をリードし研究開発, 技術, 製造，マーケットでほぼ独占していました。それにもかか わらず，優位性を活かすことなく，日本のメーカ間で過度 な競争に走ってしまいました。自社のマーケットシェアの 拡大とょり記録密度の高い, より新しい技術の開発に進 
み，自ら開発した素晴らしい技術を十分な期間，活用する ことなく「花形」(Star)，「金のなる木」(Cash cow) の商品 を「負け犬」(Dog)に早めたこともありました。研究開発 は大切で必要です。けれども, 成果を使うタイミングがあ ります。そして場合によっては開発を完了しても，その時 はまだ使用しない方が良い技術もあります。もう一つ大切 なことは日本の製造装置・機械です。製造装置・機械には 開発した技術と製造の know-how がぎっしり詰まっていま す。ですから良い製造装置を入れると製造が可能になる例 が多いのです。このように日本は, エレクトロニクスの分 野で本当に良い技術，オリジナルな技術があり，新しい技 術を生み出しているので, とても残念です。

(5) 人間に対する尊厳と優しさが欠如するようになり, 日本の良さを忘れてしまった。

イノベーション, 経営効率化, 生産効率を高めるという ことで, 従来の日本型経営の良さを捨てリストラクチャリ ングを繰り返し, 従来型の雇用体型を変え, 製造現場を派 遣労働者で置き換えて行きました。これでは，今まで重要 視し蓄積してきた日本の強みである技術, 製造, 品質, 管 理・運営の know-how は失われ，人材も育成されません。 これは本当に効率を高め, モチベーションを高める行為で しょうか? 開発, 製造など技術と現場を知らない人達が 行っているとしか考えられません。一方的に否定, 肯定す るのではありませんが, 伝統の良さ, 日本の良さを尊重す ることは，大切な何かがあります。これを失ってしまった のです。結局, 1. は技術, 製品の差別化の大切さ，2.は国 際性, 3. は正しい「ものつくり」を考える必要, 4. は協力 とバランス, 5. は経営の本質, モチベーションを高める, ということです。さらに付け加えると，6. 人間性 (人徳), 人を活かし幸福にする企業, です。見かけではなく本質を 見抜くことが大切です。単なる外的や技術的問題だけでは なく、これらの欠如にも大きな原因があります。

実装技術は日本の中で，世界に対してエレクトロニクス 産業と共に貢献して伸びてきました。これは本当に重要な ことです。けれども，日本は「ものつくり」の空洞化と発 展途上国の製造の勢いで現在, 苦境に立っています。これ からは, 同じ土俵や今までと同じ条件で生産, 対応するこ とは困難です。それは別の観点, 地球環境の急激な悪化, 地球温暖化の急速な進行, さまざまな深刻な地球環境問題 を見ても分かります。けれども, 日本のエレクトロニクス 産業と実装技術はこれらの問題を解決するために, これか らが本当に必要な時で, ステップアップする可能性があり ます。世界に貢献でき，ビジネスに成り得る成長分野を簡 単に列挙します。(1) 制御・パワー工学関係 : (1)電力技術 (2)制御工学 (3)バイラテラルコントロール (2) デバイス・ 電子機器光学関連技術 : (1)デバイス基盤技術 (2)高機能集 積回路技術 (3)フォトニクスデバイス技術 (4)エネルギエ レクトロニクス技術 (5)ワイヤレスデバイス技術 (6)セン
シング技術 (3) 通信電子システム関連技術：(1)情報通信シ ステム（2)電子システム技術（3)情報メディア技術 (4) ディペンダブル ICT などです ${ }^{3)}$ 。全てにとって実装技術は 必要で重要な役割を果たします。これらの技術は，持続可 能な社会 (Sustainable Society), 持続可能な発展 (Sustainable Development)の実現の為に貢献する環境技術，ICT， EV， $\mathrm{FCV}$, 再生可能エネルギ, ライフサイエンス, ナノテクノロ ジー, 材料, などの分野に必要不可欠です。実装分野の貢 献する技術，ビジネス分野の可能性は多くあります。けれ ども，安価な製品や大量生産の波に飲まれてはいけません。 特別な理由と必然性がない限り, モジュラー型のアセンブ リー主体のコスト競争の業種, 誰でもできる分野に下りて 行ってはいけません。日本として企業として誇りのある, 企業の顔の見える技術・製品を“made in Japan”，“made in 企業（ブランド）”で製造することを目指すことが大切で す。今，先進国は“もの”“情報”が溢れていますが，発展 途上国の中には平和と安全も充分に得られず “もの”“情 報”だけでなく“水”“食料”や“きれいな空気”さえ手に 入らない人が大勢います。私達は世界情勢を考皇ながらビ ジネスを構成する必要があります。ピンチはチャンスです。

以前，体制が大きく変わり，人心が一変してしまい，あ る時から利益のみを強く求め「10\%クラブ」(利益率 $10 \%$ ) や数值管理を強調し「社員より株主が大切」と話した企業 がありました。本当にそれで良いのでしょうか？しばら くすると本当の結果が出てきます。

経営者の先輩が 1980 年代から 1990 年代初めに話してく れた言葉が思い浮かびます。「日本で生産することを大切に する。」「社員が大切です。人が大切です。」「良いものを開 発しょう。社会の役に立つものを作らう。」「半分は自分の 好きなことをやりなさい。」そこに利益の言葉はありません でしたが，多くの人達は幸せそうに一所䁻命働いており， 良い製品を社会に提供しきちんと利益を上げていました。 今とは時代が違うかもしれません。けれども，「温故知新」 です。そして，人間のモチベーション，正しさに多くの違 いは生じていないと思います。たかだか数十年, 産業革命 からでも 250 年くらいです。人類の歴史, 地球の歴史で考 えると一瞬です。人の DNA，心の本質はそんなに急激に変 われるものではありません。最近, 井深 大さんや本田宗 一郎さんの言葉に感じます。人間は, 利益や数字でなく 「心意気に感じる」ことがあります。

技術, 自然科学の大切さと社会科学の大切さを認識する とともにエレクトロニクス産業に役立ち，共に歩んできた 実装技術の大切さを再認識し，これからの日本の産業，世 界への貢献を考えることは，実装技術がどのような方向 に，どのように貢献するかを決める手がかりになります。 そしてエネルギと資源の重要性を再認識することが大切で す。この時, 持続可能性と環境保全 (環境調和型実装技術) を考えることが必要です。私達の次の世代，子供や子孫が 
持続可能な幸せな生活を行うためには自然科学と社会科学 の融合が必要であり, エレクトロニクスと実装技術の果た す役割はとても大きいと感じます。東北大学の私たち研究 チームは現在, 「東北復興次世代エネルギー研究開発プロ ジェクト」を推進すると共に, LED 照明の $1 / 100$ の電力使 用の新しい照明デバイス, 新しいリチウムイオン 2 次電池 とそれを用いた再生可能エネルギシステムの開発などに従 事しています ${ }^{4)}$ 。日本発，オリジナルで世界に貢献する技 術開発とそのビジネスの可能性は日本, 企業, エレクトロ ニクス，実装技術の中にまだたくさんあります。それで は, 環境調和型実装技術委員会, 環境と実装研究会が提案 して来た技術について見てみましょう。

\section{2. 光利用環境技術}

国内の総電力消費量に占める照明の割合は約 $16 \%$ と高 く,これらを低減する技術は，省エネ， $\mathrm{CO}_{2}$ 削減に向けた 重要技術となっています。現在, 普及が進んでいる LED 照 明は, 従来照明の置き換えが進むと 2015 年には約 1 兆円程 度の市場規模になると予想されています 5)。このため LED 製品関連の材料開発も積極的に進められています。応用面 では，植物工場のように，省エネルギな LED 照明を用いた 新しい農業の姿が提案されています。環境と実装研究会で は，このように省エネ効果が大きく， かつ市場の伸びが期 待される次世代の照明技術を取り上げ，「光利用環境技術」 と題した公開研究会を開催しました。本稿では, 公開研究 会で紹介された光利用環境技術を紹介します 6)

\section{(1) CNTs を活用した省エネルギ未来照明技術}

東北大学 下位法弘

照明は 1879 年にエジソンが電灯事業を開始して依頼, 白 熱電球, 蛍光灯と変遷し, 現在は LED の普及が進んでいま す。この間着害に省エネ化が達成され, 白熱電球と比べる と LED は数分の 1 の消費電力で済みます。東北大学の下位 氏のグループでは, さらなる低消費電力化を目指し高純度 高結晶化 Single-walled carbon nanotube (SWCNT) を活用し た, 電界電子放出型平面発光デバイスの開発を進めていま す。高純度かつ高結晶化したSWCNT を電子源として用い ることが特徴で，SWCNTを塗料化した湿式塗布技術によ り発光デバイスのカソード電極を構築しています。湿式塗 布で使用する塗料に含まれる SWCNT の分散性を改良し,

SWCNT が均一に分散した塗膜薄膜の形成を実現しました。 この塗膜表面を物理的にこすり, 形成された溝の端面から SWCNT を横方向（塗膜界面に水平な方向）に露出させ, それら SWCNT が電界電子放出型電子源の役割を担いま す。横方向に露出した SWCNT の端部と対向電極の間の距 離がほぼ一定になり, カーボンナノチューブを用いた電界 電子放出型電子源の欠点であった発光面内の輝度ばらつき が解消され，蛍光面を面内均一に発光させることに成功し ました。また SWCNT の高純度高結晶化により電子放出時
のちらつき具合および寿命も格段な進化を遂げ，これらの 成果は 2014 年のライティングジャパンで紹介しております。

現在はこれら要素技術を用い, 線順次駆動方式を採用し た平面型発光デバイスの構築を進めています。線状に配列 したSWCNT 電極に矩形波信号を入力し，視覚効果による パルス発光量の増幅と蛍光体の残光特性の重ね合わせによ り平面内で LED と同等の光束量を達成する発光駆動アルゴ リズムを検討しています。本アルゴリズムによる発光消費 電力は, LED シーリングライトとの比較で約 $1 / 100$ との試 算結果を得ています。

\section{(2) 塗布型白色有機 EL の技術動向}

日立製作所 日立研究所 荒谷介和 有機 EL 材料を用いた平面照明は, 薄型で軽量, フレキ シブル性を有する, 水銀フリーであるなどの特徴を有して いますが，次世代照明として有機 EL 照明を普及させるに は, さらなる高性能化と低コスト化が必要です。高性能化 には, 高効率, 高色再現性, 制御性, 超寿命な積層発光層 構成が有利です。一方，低コスト化には高い材料利用効率 で，ロール to ロールプロセスが適用できる塗布法が有利と なります。荒谷氏の研究グループでは，これらを両立でき る技術として, 積層発光層を一回の塗布で実現できる自発 多層化技術の開発に取り組んでいます。

自発多層化技術とは, 発光層内の発光ドーパントの位置 を自発的に制御・形成する技術です。表面付近のドーパン トには表面エネルギを下げる置換基を導入し，下部付近の ドーパントには下地層と強い相互材料を有する置換基を導 入しました。これにより一回の塗布で, 積層発光層の形成 が可能で, 多層化していない構造に比べると約 2.7 倍の発 光効率を達成ました。これは電荷トラップ（赤色発光ドー パント）が発光層表面に局在し, 発光層中の電荷輸送性が 向上したと推定しています。

さらなる高効率化に向け，高い蛍光量子収率を有する新 発光ドーパントの開発に取り組んでいます。分子軌道計算 による LUMO 電子密度と蛍光量子効率の相関を調へ，非発 光性部位の LUMO 電子密度が低いほど, 高い蛍光収率が得 られる傾向があることを見出し，この結果を分子設計に フィードバックし高い量子収率を有する新ドーパントを開 発しました。これに加え，電子ブロッキング層を導入し， 光取り出し効率 $45 \%$ で, 電力効率 $70 \mathrm{~lm} / \mathrm{W}$ を達成しまし た。光取り出し効率は，計算手法を確立することで，69\% まで高められることを確認し，さらなる高効率化が可能で あるとしています。

（3）昭和電工グループが提案する新しい LED 植物工場シ ステムについて 昭和電工 荒 博則 昭和電工では, 自社の強みの $\mathrm{Ga}$ 系化合物半導体を活か した新たな植物工場の提案を行っています。昭和電工で $\mathrm{Ga}$ メタルの製造研究が開始されたのは 1970 年になります。 1982 年には, GaP (可視), GaAs（赤外）LED の製造が開 
始されました。その後 2005 年には, 植物工場に適した高輝 度 InGaN（青色）LED と高輝度 4 元系（赤色）LED の製造 が開始されました。

光合成には 400 から $800 \mathrm{~nm}$ 程度の波長の光が利用され ているとされています。そのうち 420４70 nm の青色の相 当する波長は発芽に影響する波長， $640 ６ 90 \mathrm{~nm}$ の赤色は 開花に影響していることが知られています7)。昭和電工で は，この光合成の特化した LED 素子を開発していて蛍光灯 では出せない特徴を有しています。植物工場における LED 選定のポイントは, 光合成や形態形成に最適な波長である こと, 植物の生育に必要な光量が確保されている, 発光効 率が高く電気代が抑えられる, 植物に最適な赤色/青色比 で構成されていることなどが挙げられます。

山口大学農学部にてリーフレタスの栽培実験を行ったと ころ, 蛍光灯や白色 LED よりも青色 $450 \mathrm{nmLED}$ と赤色 660 $\mathrm{nm}$ や $635 \mathrm{nmLED}$ との組み合わせで良好な生育が確認され ました。特に青色と赤色 $660 \mathrm{nmLED}$ が良い結果となりまし た。昭和電工と山口大学執行教授の研究グループにて, 栽 培条件の検討を進め最適な青 / 赤色比率や照射条件の最適 化により，蛍光灯を用いた従来法にくらべ 2.5 倍の収穫が 得られることを確認しています。 $\mathrm{SHIGYO}^{\mathrm{TM}}$ 法と呼ばれる これらの栽培方法は同じ光量で栽培したとすると, 従来よ りも栽培期間の短縮, 電気代の節約になり, 全国の植物工 場で採用が広がっています。

昭和電工では植物工場の事業化検討から稼動までソ リューションを提供し, 建設から栽培, 収穫にかけて, LED 照明, 栽培棚, 炭酸ガス, 断熱パネル, 反射板, 水養 液を供給しています。SHIGYO ${ }^{\mathrm{TM}}$ 法は, 全国で 15 工場が稼 動し, 今後 20 工場近くの建設が予定されています。その 他, 実証実験中や検討中の案件を含めると 100 社以上が検 討を行っています。

\section{（4）LED 配線基板用耐熱性樹脂}

横浜国立大学 高橋昭雄

今後の需要の伸びが期待される照明用の白色LEDモジュー ルのパッケージングは，反射板と配線を有するケースにLED チップを搭載し，ワイヤボンディングした後蛍光体を含む 封止樹脂で封止した構造です。パッケージにおける課題 は, 封止樹脂の透明性の確保, モジュール全体の高放熱 化, 白色反射板の変色防止が挙げられます。封止樹脂は高 温で紫外光を発する LED に接触するため, 熱光安定性にす ぐれた樹脂であることが必須の条件になります。これらの 条件満たすものとして, エポキシ樹脂とシリコーン樹脂が 選ばれLEDに用いられています。ケース樹脂は, 機械強度 が高く, 耐熱性が高い, ポリカーボネート, ポリフタルア ミド, ビスマレイミドトリアジン樹脂, 液晶ポリマーなど が用いられています。

封止樹脂として用いられるエポキシ樹脂は, 液状の脂環 式エポキシ樹脂や, ビスフェノール $\mathrm{A}$ 型エポキシ樹脂など
が一般的に用いられています。線膨張係数の低減や強度向 上と透明性を両立するためナノフィラを配合するなどの改 良もおこなわれています。耐熱性を改善するため, トリア ジン環を有するエポキシ樹脂を配合することで低粘度でガ ラス転移温度を向上できることが示されています。

このほか LED のほかさまざまな耐熱用途で展開が可能 な, 多環芳香族系エポキシ樹脂, エポキシ変性ベンゾオキ サジン樹脂, エポキシ変性シアネートエステル樹脂の分子 構造と特性に関する紹介がありました。

\section{3. むすび}

産業革命以降の目覚ましい技術の発達はエレクトロニク 久，実装技術に目覚ましい発展をもたらしました。けれど も今, 日本の製造業の低迷と持続可能性の崩壊など, 大き な転換点にいます。従来型の発展, 経済成長では持続可能 性を維持できず，格差の拡大を増長します。地球に限界が あることを知った今，私達は得意とするエレクトロニク ス，実装技術を再考し，行動することが求められていま す。ここでは，環境調和型実装技術委員会の現状掞よび展 望と環境と実装研究会による公開研究会「光利用環境技術」 に打けるトピックス技術を紹介しました。当技術委員会お よび研究会では, 環境と実装の接点を広い視野でウォッチ ングし，今後も積極的に情報発信していきます。

\section{文責・田中泰光 $/$ 東北大学} 石井利昭 $/$ 日立製作所

(2014.11.5- 受理)

\section{文献}

1)「日本の経済」,「人口爆発」, Wikipedia

2）藤田哲雄：“我が国の電機産業の再生に向けて,”JRI レ ビュー, Vol. 6, No. 7, p. 57, 2013

3) “電機電子工学分野の展望, ” 日本学術会議, 電気電子委員 会, 平成 22 年 4 月 5 日

4)「東北復興次世代エネルギー研究開発プロジェクト」, NET, 東北大学, http://net-tohoku.sakura.ne.jp/wp/

5）LED 照明推進協議会 HP, http://www.led.or.jp

6) 光利用環境技術 : 環境と実装研究会 2014 年度第 1 回公開研 究会予稿集, 2014-5-29

7) LED2008- 技術と応用の新展開, 日経 BP

田中泰光（たなか やすみつ）

著者紹介

東北大学大学院 環境科学研究科 教授, 環境物質制御学, 国際エネル ギー資源戦略を立案する環境リーダー育成拠点 http://www.kankyo。 tohoku.ac.jp/sermss/

慶應義塾大学工学研究科 博士課程前期, 東北大学工学研究科 博士課 程後期修了, エレクトロニクス企業に勤務, 研究開発, 製造技術, 海外 工場に従事，現在に至る。

石井利昭（いしい としあき）

(株) 日立製作所 日立研究所 材料研究セン夕 主管研究員, 工学博士 1989 年 北海道大学理学研究科 高分子科学科修士課程修了, 同年 日 立研究所入所, 半導体実装材料の開発に従事, 現在に至る。 